\title{
Effectiveness of Cytozyme Products Over Yield and Juice Quality in Sugarcane Ratoon Crop
}

\author{
Varucha Misra, A.K. Mall* and A.K. Shrivastava \\ ICAR-Indian Institute of Sugarcane Research Lucknow-226 002 (U. P.), India \\ *Corresponding author
}

\section{A B S T R A C T}

\begin{tabular}{|c|c|}
\hline & \multirow{6}{*}{$\begin{array}{l}\text { Ratooning in sugarcane is a common practice in sugarcane as it saves cost of } \\
\text { planting material and preparatory tillage and also germinates faster than the seed } \\
\text { material. Several chemicals have been used in enhancing the production and } \\
\text { productivity. In this regard, the effectiveness of Cytozyme Products over yield and } \\
\text { juice quality in sugarcane ratoon crop was assessed. Two ratoon crops were } \\
\text { initiated in both the seasons, i.e., autumn and spring using an early ripening and } \\
\text { high sugar variety, CoPk 05191, in different fields. Growth parameter and juice } \\
\text { quality analyses were performed to assess the effect of this chemical. The } \\
\text { application of cytozyme showed minor improvement in ratoon crop raised from } \\
\text { autumn and spring planted crop productivity, although, no positive effect was } \\
\text { observed in juice quality of the ratoon crop of both autumn and spring planted } \\
\text { crop. Keywords: Cytozyme, Juice quality, Ratoon crop, Yield }\end{array}$} \\
\hline Keywords & \\
\hline & \\
\hline Article Info & \\
\hline & \\
\hline & \\
\hline
\end{tabular}

\section{Introduction}

Ratooning in sugarcane is a characteristic of basic importance exploiting the sugarcane crop for higher profitability. The reason behind is the reduction of high amount of investment required in planting a sugarcane crop (Chapman and Wilson, 1996). In respect to the environmental advantages, ratoon crops have several benefits like reduction in the frequency of soil preparation generally required in plant crop of sugarcane. One of the major importances of ratoon initiation in sugarcane crop is prevention of soil erosion phenomenon which is generally a frequent phenomenon in places where agriculture is performed as it occurs when tillage is applied to the soil before the cane planting is performed. This even implies that when rate of ratoon cultivation in sugarcane becomes higher there is lesser probability of soil erosion (Lal, 1998).

Being an economical cash crop, sugarcane is a commercially important crop in the world. Besides its main product sugar, the production of ethanol in respect to emerging needs makes it more important cultivation crop, both for farmers and millers. As cane area is restricted to a limited extent and cannot be further enhanced researches are being conducted to enhance the production and its productivity by any means of method (Vision, 2040). Use of several chemicals is one such way to enhance it, however, how much it will cause negative effect on health has not been seen in 
some of the chemicals applied. The present study uses Cytozyme's product Crop ${ }^{\mathrm{TM}}$ and Seed $+{ }^{\mathrm{TM}}$ where the former is obtained from concentrates from algae, Ascophyllum nodosum while latter is a fertiliser of vegetable origin obtained from fermentation and chemical treatment of the vegetable, seaweed product. Wozniak and Martineau (2007) had showed the positive effects in plant productivity of many crops. Also on chlorophyll content, photosynthetic activity was assessed in selected model plants and field crops and showed positive results. The association of these parameters in respect to yield had also showed an enhancement. However, researches have not yet been conducted on application of Cytozyme's product over sugarcane crop. Therefore, the study was to assess the effectiveness of Cytozyme products on sugarcane growth, yield and juice quality parameters particularly in ratoon crop.

\section{Materials and Methods}

\section{Crop culture}

Two ratoon crops were initiated in both the seasons, i.e., autumn and spring using an early ripening and high sugar variety, CoPk 05191, in different fields at ICAR-Indian Institute of Sugarcane Research, Lucknow farm. These fields were prepared using cultivator and harrow where the furrows were opened at 90 $\mathrm{cm}$ row-to-row spacing with the help of tractor mounted furrower. In both seasons of sugarcane ratoon, two chemical treatments were applied.

The experiment was conducted in Randomized Block Design (RBD) with two replications while plot area was $8 \times 5.4 \mathrm{~m}$. The fertilizer dose in the experiment field was given as per normal practice, i.e., $150 \mathrm{Kg} \mathrm{N}$ in three splits; $80 \mathrm{Kg} \mathrm{P}_{2} \mathrm{O}_{5}$ as DAP (Basal) and $80 \mathrm{~kg} \mathrm{~K} \mathrm{~K}_{2} \mathrm{O}$ as MOP (Basal). Proper care and all essential cultural practices were being taken for healthy ratoon initiation. The first treatment comprises of two sprays of different chemicals at different time of crop age, assigned as $T_{1}$. Of these two sprays, first spray was of Crop XL at $1000 \mathrm{ml} \mathrm{ha}^{-1}+$ Cytro Nutri Zinc $750 \mathrm{ml} \mathrm{ha}^{-1}$ was sprayed when ratoon crop age was five months and have attained crop canopy of $55 \mathrm{~cm}$ followed by the second spray of Crop XL at $1000 \mathrm{ml} \mathrm{ha}^{-1}$ + Cytro Nutri Boron $750 \mathrm{ml} \mathrm{ha}^{-1}$ and Cyto Nutri potassium $1000 \mathrm{ml} \mathrm{ha}^{-1}$ on after subsequent a month (or three weeks) of first spray. In the second treatment, $\mathrm{T}_{2}$, in both the seasons, at the time of ratoon initiation, Seed + Extra at $500 \mathrm{ml} \mathrm{ha}^{-1}$ with Soil + at $500 \mathrm{ml}$ $\mathrm{ha}^{-1}$ was sprayed directly onto the ratoon that were initiated in different furrows of plant crop and thereafter the first spray and second spray of chemicals was given as that of the first treatment. During both the sprays, the Control was sprayed with water only.

\section{Growth parameters analysis}

Growth parameter analysis was performed to assess the effect of chemicals over sugarcane growth in ratoon crop. Number of tillers was counted during the tillering period of sugarcane to determine maximum number of tillers in ratoon crop. Cane weight of different treated canes was measured by weighing balance.

\section{Juice quality analysis}

Juice quality analysis was analysed in both autumn and spring raised ratoon crop. Reducing sugars were estimated by Nelson Somoygii method. Purity coefficient was calculated by the formula- (Sucrose $(\%) /{ }^{\circ}$ Brix) x 100 . Sucrose $(\%)$ was measured by polarimeter through lead acetate method. ${ }^{\circ}$ Brix was measured by hand refractometer. $\mathrm{pH}$ was measured by $\mathrm{pH}$ meter. CCS (\%) was calculated by the formula CCS $(\%)=1.022 \mathrm{~S}$ 0.292B (S-Sucrose and B- ${ }^{\circ}$ Brix). 


\section{Results and Discussion}

\section{Maximum number of tillers}

In the ratoon crop raised from the autumn planted crop (RAP), the maximum number of tillers (Tmax) increased by $35.53(\%)$ in $\mathrm{T}_{2}$ and $25.72(\%)$ in $\mathrm{T}_{1}$ under normal irrigated conditions while in the spring planted crop (RSP), Tmax increased by $6.67(\%)$ in $\mathrm{T}_{1}$ and $4.03(\%)$ in $\mathrm{T}_{2}$. This indicated that both $\mathrm{T}_{1}$ and $\mathrm{T}_{2}$ treatments were effective on maximum number of tillers as compared to control, however, $\mathrm{T}_{2}$ showed better effectiveness than $\mathrm{T}_{1}$ in autumn ratoon crop while it was viceversa in spring ratoon crop (Table 1).

\section{Number of Millable Canes (NMC/ha)}

The number of millable canes per ha (NMC $\mathrm{ha}^{-1}$ ) in the ratoon crop raised from autumn and spring plant crops are given in table 2 . In the ratoon crop raised from the autumn planted crop (RAP), under normal irrigated conditions, NMC ha ${ }^{-1}$ increased by $8.6(\%)$ in $\mathrm{T}_{1}$ and $13.72(\%)$ in $\mathrm{T}_{2}$. In ratoon raised from the spring planted crop (RSP), under normal irrigated conditions, NMC/ha increased by $7.17(\%)$ in $\mathrm{T}_{1}$ and practically no change in $\mathrm{T}_{2}$.

\section{Average cane weight ( $\left.\mathrm{kg} \mathrm{cane}^{-1}\right)$}

In autumn ratoon crop, average cane weight (ACW) increased by 8.7 to $8.9(\%)$ in both the treatments, $\mathrm{T}_{1}$ and $\mathrm{T}_{2}$ in comparison to control while in the spring ratoon crop, ACW decrease by nearly $20(\%)$ in both the treatments, $\mathrm{T}_{1}$ and $\mathrm{T}_{2}$ in comparison to control. This showed that although both the treatments were effective on average cane weight but $T_{2}$ treatment was slightly better than $T_{1}$ treatment in autumn ratoon initiated crop while both the treatments fail to show its effectiveness in spring ratoon crop (Table 3 ).

\section{Cane yield}

In the ratoon crop raised from the autumn planted crop (RAP), cane yield decreased by 5.1 and $13.96(\%)$ in treatments $\mathrm{T}_{1}$ and $\mathrm{T}_{2}$, respectively, but in ratoon crop raised from the preceding spring planted crop (RSP), cane yield increased by $7(\%)$ in $\mathrm{T}_{1}$ and by 17.26 (\%) in $\mathrm{T}_{2}$ as compared to Control (Table 4). This showed that both treatments applied on ratoon crop showed effectiveness on cane yield. In autumn ratoon crop, both the treatments fail to give positive results while in spring ratoon crop, $\mathrm{T}_{2}$ showed better results than $\mathrm{T}_{1}$.

\section{Juice quality parameters}

Total soluble solids: In autumn planted crop, ${ }^{\circ}$ Brix was increased by $0.15(\%)$ in $\mathrm{T}_{1}$ while it was decreased by $5.34(\%)$ in $\mathrm{T}_{2}$ as compared to Control. However in spring raised ratoon crop, ${ }^{\circ}$ Brix was decreased by $2.26(\%)$ in $\mathrm{T}_{1}$ and $7.34(\%)$ in $\mathrm{T}_{2}$. This showed that in spring ratoon crop both the treatments showed no effective results while in autumn raised ratoon $\mathrm{T}_{1}$ showed a slight improvement in ${ }^{\circ} \mathrm{Brix}$ but in $\mathrm{T}_{2}$, there was no effect on ${ }^{\circ} \mathrm{Brix}$ rather negative effect was seen (Table 5).

Table.1 Tmax/ha in the ratoon crop raised from autumn and spring planted crop

\begin{tabular}{|c|c|c|c|c|c|c|c|c|c|}
\hline \multirow{2}{*}{\multicolumn{2}{|c|}{ Treatment }} & \multicolumn{2}{|l|}{$\mathrm{R}_{1}$} & \multicolumn{2}{|l|}{$\mathrm{R}_{2}$} & \multicolumn{2}{|c|}{ Mean of $R_{1}$ and $R_{2}$} & \multicolumn{2}{|c|}{$\begin{array}{l}\text { Per cent change } \\
\text { (DT) }\end{array}$} \\
\hline & & Autumn & Spring & Autumn & Spring & Autumn & Spring & Autumn & Spring \\
\hline $\mathrm{C}$ & Control & 390077 & 571805 & 355121 & 614632 & 372599 & 593218 & - & - \\
\hline $\mathrm{T}_{1}$ & FSP & 494484 & 647274 & 442396 & 618568 & 468440 & 632921 & 25.72 & 6.67 \\
\hline $\mathrm{T}_{2}$ & $\begin{array}{l}\text { Freshly harvested } \\
\text { stubble + Soil + FSP }\end{array}$ & 504901 & 632921 & 505133 & 601437 & 505017 & 617179 & 35.53 & 4.03 \\
\hline
\end{tabular}

Nb. DT: due to treatment 
Table.2a NMC $\mathrm{ha}^{-1}$ in the ratoon crop raised from autumn planted sugarcane

\begin{tabular}{|l|l|l|l|l|l|}
\hline \multicolumn{2}{|c|}{ Treatment } & $\mathrm{R}_{1}$ & $\mathrm{R}_{2}$ & $\begin{array}{l}\text { Mean of } \mathrm{R}_{1} \\
\text { and } \mathrm{R}_{2}\end{array}$ & $\begin{array}{l}\text { Per cent change } \\
(\mathrm{DT})\end{array}$ \\
\hline $\mathrm{C}$ & Control & 162281 & 171773 & 167027 & - \\
\hline $\mathrm{T}_{1}$ & FSP & 183348 & 178949 & 181448 & 8.6 \\
\hline $\mathrm{T}_{2}$ & Freshly harvested stubble + Soil + FSP & 178023 & 201868 & 189945 & 13.72 \\
\hline
\end{tabular}

$\mathrm{Nb}$. DT: due to treatment

Table.2b NMC/ha in the ratoon crop raised from spring planted sugarcane

\begin{tabular}{|l|l|l|l|l|l|}
\hline \multicolumn{2}{|c|}{ Treatment } & $\mathrm{R}_{1}$ & $\mathrm{R}_{2}$ & $\begin{array}{l}\text { Mean of } \mathrm{R}_{1} \\
\text { and } \mathrm{R}_{2}\end{array}$ & $\begin{array}{l}\text { Per cent change } \\
(\mathrm{DT})\end{array}$ \\
\hline $\mathrm{C}$ & Control & 172930 & 197932 & 185431 & - \\
\hline $\mathrm{T}_{1}$ & FSP & 185663 & 211822 & 198742 & 7.17 \\
\hline $\mathrm{T}_{2}$ & Freshly harvested stubble + Soil + FSP & 190293 & 179644 & 184968 & -0.25 \\
\hline
\end{tabular}

Nb. DT: due to treatment

Table.3 ACW ( $\left.\mathrm{kg} \mathrm{cane}^{-1}\right)$ in the ratoon raised from autumn (A) and spring (S) ratoon sugarcane

\begin{tabular}{|c|c|c|c|c|c|c|c|c|c|}
\hline \multirow{2}{*}{\multicolumn{2}{|c|}{ Treatment }} & \multicolumn{2}{|l|}{$\mathrm{R}_{1}$} & \multicolumn{2}{|l|}{$\mathrm{R}_{2}$} & \multicolumn{2}{|c|}{ Mean of $R_{1}$ and $R_{2}$} & \multicolumn{2}{|c|}{$\begin{array}{l}\text { Per cent change } \\
\text { (DT) }\end{array}$} \\
\hline & & $\mathrm{A}$ & $\mathrm{S}$ & A & $\mathrm{S}$ & $\mathrm{A}$ & $\mathrm{S}$ & A & $\mathrm{S}$ \\
\hline $\mathrm{C}$ & Control & 0.98 & 1.39 & 0.99 & 1.03 & 0.99 & 1.21 & - & - \\
\hline $\mathrm{T}_{1}$ & FSP & 0.82 & 0.96 & 0.98 & 0.99 & 0.90 & 0.97 & 8.92 & -19.50 \\
\hline $\mathrm{T}_{2}$ & Freshly harvested stubble + Soil + FSP & 0.92 & 0.98 & 0.88 & 0.93 & 0.90 & 0.96 & 8.72 & -21.03 \\
\hline
\end{tabular}

$\mathrm{Nb}$. DT: due to treatment

Table.4 Cane yield $\left(\mathrm{t} \mathrm{ha}^{-1}\right)$ in the ratoon raised from autumn and spring ratoon crop

\begin{tabular}{|c|c|c|c|c|c|c|c|c|c|}
\hline \multirow{2}{*}{\multicolumn{2}{|c|}{ Treatment }} & \multicolumn{2}{|c|}{$\mathrm{R}_{1}$} & \multicolumn{2}{|c|}{$\mathrm{R}_{2}$} & \multicolumn{2}{|c|}{ Mean of $R_{1}$ and $R_{2}$} & \multicolumn{2}{|c|}{$\begin{array}{l}\text { Per cent change } \\
\text { (DT) }\end{array}$} \\
\hline & & A & $\mathrm{S}$ & A & $\mathrm{S}$ & A & $S$ & A & $S$ \\
\hline C & Control & 197.98 & 132.25 & 152.77 & 130.53 & 173.37 & 131.39 & - & -11.34 \\
\hline $\mathrm{T}_{1}$ & FSP & 175.88 & 145.48 & 150.69 & 135.68 & 163.28 & 140.58 & -5.81 & -27.16 \\
\hline $\mathrm{T}_{2}$ & $\begin{array}{l}\text { Freshly harvested } \\
\text { stubble + Soil + FSP }\end{array}$ & 143.63 & 166.56 & 154.69 & 141.59 & 149.16 & 154.07 & -13.96 & -23.44 \\
\hline
\end{tabular}

$\mathrm{Nb}$. DT: due to treatment

Table. $5^{\circ}$ Brix in the ratoon crop raised from autumn and spring planted crop

\begin{tabular}{|c|c|c|c|c|c|c|c|c|c|}
\hline & \multirow[t]{2}{*}{ Treatment } & \multicolumn{2}{|l|}{$\mathrm{R}_{1}$} & \multicolumn{2}{|l|}{$\mathrm{R}_{2}$} & \multicolumn{2}{|c|}{ Mean of $R_{1}$ and $R_{2}$} & \multicolumn{2}{|c|}{$\%$ change $(\mathrm{DT})$} \\
\hline & & $\mathrm{A}$ & $\mathrm{S}$ & A & $S$ & A & $S$ & A & $S$ \\
\hline $\bar{C}$ & Control & 19.02 & 18.13 & 18.78 & 18.10 & 18.90 & 18.11 & - & - \\
\hline $\mathrm{T}_{1}$ & FSP & 19.10 & 19.09 & 18.77 & 16.31 & 18.93 & 17.70 & +0.15 & -2.26 \\
\hline $\mathrm{T}_{2}$ & $\begin{array}{l}\text { Freshly harvested stubble } \\
\text { Soil + FSP }\end{array}$ & +18.06 & 19.13 & 17.73 & 14.43 & 17.89 & 16.78 & -5.34 & -7.34 \\
\hline
\end{tabular}

$\mathrm{Nb}$. DT: due to treatment 
Table.6 Pol (\%) in the ratoon crop raised from autumn and spring planted crop

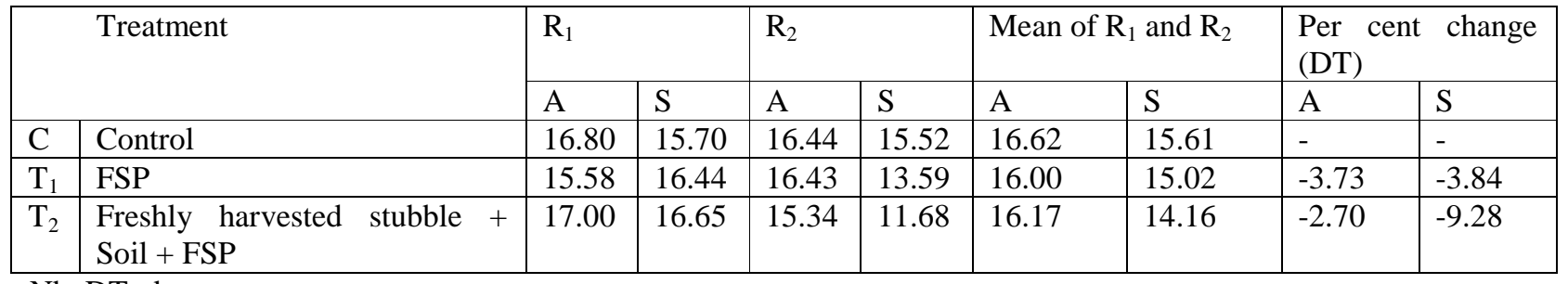

$\mathrm{Nb}$. DT: due to treatment

Table.7 Purity co-efficient in the ratoon crop raised from autumn and spring planted crop

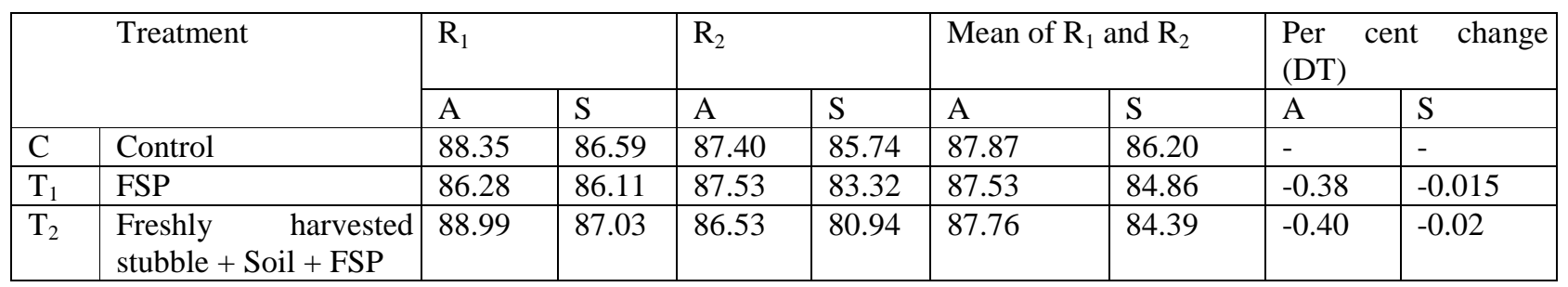

$\mathrm{Nb}$. DT: due to treatment

Table.8 Reducing sugars ( $\mathrm{mg} \mathrm{ml}^{-1}$ juice) in the ratoon crop raised From autumn and spring planted crop

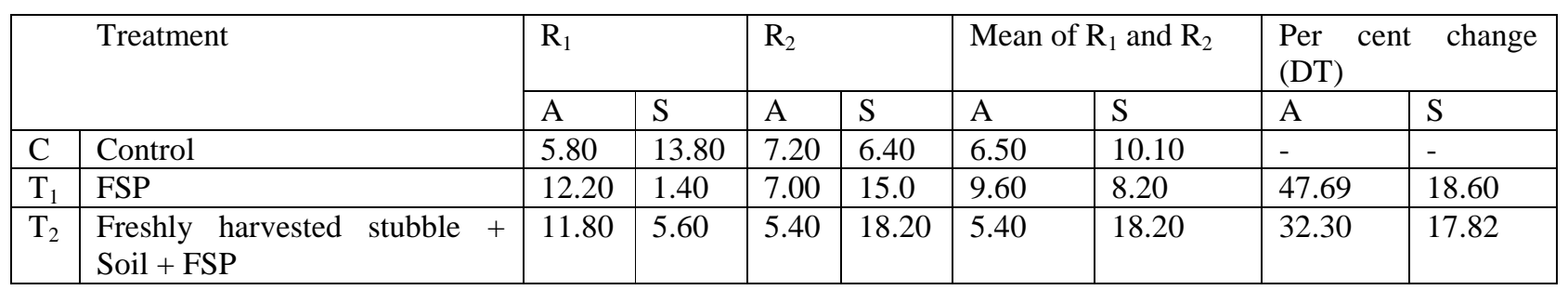

$\mathrm{Nb}$. DT: due to treatment

Table.9 $\mathrm{pH}$ in the ratoon crop raised from autumn and spring planted crop

\begin{tabular}{|c|c|c|c|c|c|c|c|c|c|}
\hline & \multirow[t]{2}{*}{ Treatment } & \multicolumn{2}{|l|}{$\mathrm{R}_{1}$} & \multicolumn{2}{|l|}{$\mathrm{R}_{2}$} & \multicolumn{2}{|c|}{ Mean of $R_{1}$ and $R_{2}$} & \multicolumn{2}{|c|}{$\begin{array}{l}\text { Per cent change } \\
\text { (DT) }\end{array}$} \\
\hline & & A & $\mathrm{S}$ & $\mathrm{A}$ & $\mathrm{S}$ & $\mathrm{A}$ & $\mathrm{S}$ & A & $\mathrm{S}$ \\
\hline $\mathrm{C}$ & Control & 5.24 & 5.16 & 5.27 & 5.21 & 5.25 & 5.18 & - & - \\
\hline $\mathrm{T}_{1}$ & FSP & 5.19 & 5.27 & 5.28 & 5.17 & 5.23 & 5.22 & -0.38 & 0.77 \\
\hline $\mathrm{T}_{2}$ & $\begin{array}{l}\text { Freshly harvested stubble }+ \text { Soil }+ \\
\text { FSP }\end{array}$ & 5.29 & 5.24 & 5.18 & 5.12 & 5.23 & 5.18 & -0.38 & 0.0 \\
\hline
\end{tabular}

$\mathrm{Nb}$. DT: due to treatment

Pol $(\%)$

In autumn planted crop, pol (\%) was decreased by $3.73(\%)$ in $\mathrm{T}_{1}$ while it was decreased by $2.70(\%)$ in $\mathrm{T}_{2}$ as compared to Control.
However in spring raised ratoon crop, pol (\%) was decreased by $3.84(\%)$ in $\mathrm{T}_{1}$ and $9.28(\%)$ in $\mathrm{T}_{2}$ (Table 6). This showed that in spring and autumn raised ratoon crop, both the treatments showed no effective results. 


\section{Purity coefficient}

In autumn planted crop, purity co-efficient was decreased by $0.38(\%)$ in $\mathrm{T}_{1}$ while it was decreased by $0.40(\%)$ in $\mathrm{T}_{2}$ as compared to Control. However in spring raised ratoon crop, purity coefficient was decreased by $0.015(\%)$ in $\mathrm{T}_{1}$ and $0.02(\%)$ in $\mathrm{T}_{2}$ (Table 7). This showed that in spring and autumn raised ratoon crop, both the treatments showed no negative results.

\section{Reducing sugars $\left(\mathrm{mg} \mathrm{ml}^{-1}\right)$}

In autumn planted crop, reducing sugars was increased by $47.69(\%)$ in $\mathrm{T}_{1}$ while it was increased by $32.30(\%)$ in $\mathrm{T}_{2}$ as compared to Control. However, in spring raised ratoon crop, reducing sugars was increased by 18.60 $(\%)$ in $\mathrm{T}_{1}$ and $17.82(\%)$ in $\mathrm{T}_{2}$ (Table 8). This showed that in spring and autumn raised ratoon crop, both the treatments showed no effective results as much higher increase in reducing sugars were observed. In comparing both the planting seasons much higher reducing sugars were seen in comparison to autumn raised ratoon crop.

\section{pH}

In autumn planted crop, $\mathrm{pH}$ was decreased by $0.38(\%)$ in $\mathrm{T}_{1}$ while it was decreased by 0.38 $(\%)$ in $\mathrm{T}_{2}$ as compared to Control. However, in spring raised ratoon crop, reducing sugars was increased by 0.77 in $T_{1}$ and no difference in $\mathrm{T}_{2}$ as compared to Control (Table 9).

This field study on ratoon crop showed that in ratoon crop raised from autumn and spring planted crop had improvement in ratoon cane productivity however, in respect to juice quality of the ratoon crop of both autumn and spring planted crop showed no positive effect by application of Cytozyme. There is still need of further research on the application of Cytozyme over nutrients in the crop. Acknowledgement: Authors are obliged to Director, ICAR-Indian Institute of Sugarcane Research, Lucknow for providing the facilities for conduction of experiment.

\section{References}

Nelson N. 1944 A photometric adaption of Somogyi method for determination of reducing sugar. J. Biol. Chem., 153:375-380.

Wozniak, E.M. and J.R. Martineau. 2007. Cytozyme's Products for Sustainable Agriculture and their Advantages over Other Products on the Market. Plant Nut. For Sust. Agric., 10 (1): 1-6

Lal, R. 1998. Soil erosion impact on agronomic productivity and environmental quality. Critical Reviews in Plant Sciences, 17 (4): 319-464.

Chapman, L. S. and Wilson, J. R. 1996. Economics of ratoon cycle length in sugarcane crop, pp. 169-171. In Wilson JR, Hogartsh D.M., Campbell J, A. Garside A. L. (eds). Sugarcane Research towards Efficient and Sustainable Production. CSIRO Div. of Tropical Crops and Pastures, Brisbane.

\section{How to cite this article:}

Varucha Misra, A.K. Mall and Shrivastava, A.K. 2017. Effectiveness of Cytozyme Products Over Yield and Juice Quality in Sugarcane Ratoon Crop. Int.J.Curr.Microbiol.App.Sci. 6(6): 2294-2299. doi: https://doi.org/10.20546/ijcmas.2017.606.272 